Ecology, 1992, v.73, n.5, pp.1662-1674.

ISSN: 0012-9658

DOI: $10.2307 / 1940018$

http://www.esajournals.org/loi/ecol

(c) 1992 by the Ecological Society of America. 


\title{
INDIRECT EFFECTS OF PREDATION IN A FRESHWATER, BENTHIC FOOD CHAIN ${ }^{1}$
}

\author{
CHRISTER BRÖNMARK \\ Department of Ecology, University of Lund, Ecology Building, S-223 62 Lund, Sweden \\ STEVen P. KLOSIEWSKI ${ }^{2}$ AND Roy A. STEIN \\ Department of Zoology, The Ohio State University, 1735 Neil Avenue, Columbus, Ohio 43210 USA
}

\begin{abstract}
Theories of cascading trophic interactions provide specific predictions regarding the forces that regulate populations across trophic levels. Reducing predators in a food chain with three trophic levels should permit herbivores to increase, thus reducing primary producers. In a manipulative experiment involving a molluscivorous fish (pumpkinseed sunfish, Lepomis gibbosus), freshwater snails, and periphytic algae, we tested this prediction. With 10 cages $(3 \times 3 \times 2 \mathrm{~m})$ in each of two lakes in northern Wisconsin, we generated three treatments: exclosures (fishless), enclosures (three pumpkinseed sunfish), and cageless controls, both in Mann Lake, which had high natural densities of pumpkinseed sunfish (HDP), and in Round Lake, which had low densities (LDP). During a 16-mo experiment, we quantified snail and periphyton biomass on plastic flagging within treatments during summer at 3- and 6-wk intervals in 1986 and 1987, respectively.

Predation by pumpkinseed sunfish reduced snail biomass on flagging, permitting periphyton biomass to increase, as compared to exclosures. As expected, periphyton biomass in cageless controls in Mann Lake (HDP) mirrored periphyton biomass in enclosures, whereas cageless controls in Round Lake (LDP) differed from exclosures. The periphyton assemblage changed dramatically with increasing grazing pressure. In enclosures (low grazing), filamentous algae and large, stalked diatoms dominated the periphyton assemblage, whereas in exclosures (high grazing), assemblages were dominated by small, adnate diatoms and a colonial, filamentous bluegreen alga (Gloeotrichia). In laboratory trials, snails preferentially fed on periphyton from enclosures (where grazing pressure had been low).

Predation reduced snail density, but indirectly increased periphyton biomass, dramatically modifying species composition of the assemblage. Thus, in mesotrophic Wisconsin lakes, top-down interactions regulate the benthic, freshwater food chain.
\end{abstract}

Key words: algal assemblage; field-cage experiments; food chain theory; freshwater snails; herbivory; indirect effects; periphyton; predation; pumpkinseed sunfish; top-down effects; trophic cascade; yellow perch.

\section{INTRODUCTION}

Competition has been suggested as the primary structuring force in natural communities, though more recently the importance of environmental variability and predation has been stressed (e.g., Strong et al. 1984, Diamond and Case 1986). However, Hairston et al. (1960, hereafter HSS) pointed out that the factor regulating a specific population depends on its position in the food chain and the number of trophic levels in the chain. Thus, in a food chain with three trophic levels, predators will be resource limited, herbivores regulated by predators, and primary producers limited by the availability of resources. Recent work coupling regulating forces to trophic levels and the concepts of "cascading trophic interactions" (Paine 1980, Carpenter et al. 1985), "three-trophic-level effect" (Sih et al. 1985),

\footnotetext{
Manuscript received 4 September 1990; revised 1 November 1991; accepted 10 November 1991.

2 Present address: Migratory Bird Management, U.S. Fish and Wildlife Service, 1011 East Tudor Road, Anchorage, Alaska 99503 USA.
}

and "indirect trophic linkage effects" (Miller and Kerfoot 1987) all reflect HSS theory.

Studies in freshwater pelagic systems reveal that predators can have profound effects on prey behavior, abundance, and overall community structure (e.g., Kerfoot and Sih 1987, Carpenter 1988, Northcote 1988). Manipulations of planktivore density in mesocosm or whole-lake experiments lead to strong effects at lower trophic levels, affecting biomass, size structure, and species composition of zooplankton and phytoplankton (e.g., Henrikson et al. 1980, Shapiro and Wright 1984, Carpenter et al. 1987, Kerfoot 1987). Similar strong predator-driven interactions over several trophic levels have been documented in the marine intertidal (e.g., Paine 1966, 1980, Estes and Palmisano 1974, Lubchenco 1986, Menge and Sutherland 1987), but as yet few studies have been done in freshwater benthic communities (but see Mazumder et al. 1989, Power 1990, Weber and Lodge 1990).

To extend the general ideas of cascading trophic interactions, we examined how a periphytic algal assemblage reacted to the manipulation of a molluscivorous 
fish predator, the pumpkinseed sunfish (Lepomis gibbosus). The pumpkinseed sunfish is a highly specialized snail predator, morphologically adapted to crushing snail shells with its strong pharyngeal teeth and welldeveloped jaw muscles (Lauder 1983). A high proportion of adult pumpkinseed diets consists of snails (Sadzikowski and Wallace 1976, Mittelbach 1984, Osenberg and Mittelbach 1990); thus, this species has the potential to affect the abundance and species composition of snail assemblages. Historically, the regulatory role that predators might play in influencing distribution and abundance of snails has been minimized; most authors have emphasized calcium concentration (e.g.. Hubendick 1947). However, recent work suggests that only calcium levels $<5 \mathrm{mg} / \mathrm{L}$ prevent colonization (Aho 1984, Lodge et al. 1987); biotic interactions, especially predation, are postulated to regulate snail assemblages in calcium-rich, permanent lakes (Lodge et al. 1987). Because snail grazing modifies periphyton biomass, productivity, and species composition (see Brönmark 1989 for a review), we predicted that manipulating snail predators would indirectly affect periphyton assemblages through a direct effect on snails. Via an enclosure-exclosure experiment in two lakes, one with a high natural density of pumpkinseed sunfish and one with a low density, through two summers, we tested this aspect of the cascading trophic interaction hypothesis. In the second summer we added a treatment to evaluate the effects of yellow perch (Perca flavescens) on snails and periphyton. Yellow perch includes snails to some degree in its diet (Hanson and Leggett 1986; S. P. Klosiewski, personal observation) and occurred at high densities in the lake with a low density of pumpkinseeds.

\section{Materials AND Methods}

To quantify the indirect impact of pumpkinseed sunfish on periphyton we placed two cages and designated one control area (cages $3 \times 3 \times 2 \mathrm{~m}, 0.5-\mathrm{mm}$ mesh: one enclosure, one exclosure, one cageless control) in five locations in the littoral zone ( $1.5 \mathrm{~m}$ depth) of Mann and Round lakes, Vilas County, Wisconsin, USA. We chose Mann and Round lakes because they were of similar size (107 and 47 ha, respectively), similar in depth (6 and $8 \mathrm{~m}$, respectively), supported extensive, diverse macrophyte assemblages, and differed dramatically in pumpkinseed densities. Based on inshore electrofishing (night electrofishing of five random 50-m transects; Klosiewski 1991) in summer 1984, we estimated pumpkinseed sunfish densities in Mann and Round lakes as $0.23 \pm 0.026$ and $0.02 \pm 0.006 \mathrm{fish} / \mathrm{m}$ of shoreline (mean $\pm 1 \mathrm{SE}$ ), respectively. Following winterkill conditions during 1986/1987, pumpkinseed densities fell to $0.11 \pm 0.05 \mathrm{fish} / \mathrm{m}$ of shoreline in Mann Lake; densities in Round Lake increased somewhat to $0.05 \pm 0.019 \mathrm{fish} / \mathrm{m}$ (fish densities estimated as in 1984). Thus, though variable through time in Mann Lake, pumpkinseed densities during our 16-mo experiment were always higher in Mann Lake (High Density Pumpkinseed, HDP) than in Round Lake (Low Density Pumpkinseed, LDP). Densities of yellow perch, a potential snail predator, were high in Round Lake (0.191 individuals/ $\mathrm{m}$ of shoreline), whereas in Mann Lake the density was low $(0.009$ yellow perch $/ \mathrm{m}$ of shoreline). Running simultaneous experiments in these two lakes permitted an assessment of historical effects due to predation and provided an opportunity for evaluating the generality of our conclusions.

Three pumpkinseeds (131-160 mm total length) were placed in cages in May 1986, resulting in a density of 0.3 individuals $/ \mathrm{m}^{2}$. Osenberg et al. (1992) found a density of 1.6 pumpkinseeds $/ \mathrm{m}^{2}$ in Wintergreen Lake, Michigan. Thus, pumpkinseed densities used in enclosures are well within the range of densities found in natural habitats. Pumpkinseeds remained in enclosures through October 1986, when they were removed. To limit damage by ice during winter the upper portions of cage sides were removed and a lid added to the now $0.75 \mathrm{~m}$ high cages. In May 1987 lids were removed and upper cage walls and fish replaced. In 1987, we added three cages to Round Lake and stocked them with three yellow perch (181-209 $\mathrm{mm}$ total length) per cage.

To quantify periphyton we placed three sets of eight strips $(100 \times 3 \mathrm{~cm})$ of plastic flagging ("flags") in each cage. Flagging was anchored at one end; small styrofoam floats kept flagging vertical. Every 3 (1986) and 6 (1987) wk during summer we removed one flag from each set, cooled it immediately in $5^{\circ} \mathrm{C}$ water, and stored it at $5^{\circ}$ until processed further (within $48 \mathrm{~h}$ ). Occasionally when flags with heavy periphyton growth were lifted from the water, some loosely attached algae and detritus were lost. However, this only reduces differences among treatments, providing a conservative estimate of treatment effects. Snails present on the flags could be readily observed, and only in a few instances were any snails lost when flags were lifted from the water. In the laboratory the snails were removed and preserved in alcohol for later determination of species and length (to the nearest $0.1 \mathrm{~mm}$ ). Snail lengths were transformed to dry masses using length-dry mass regressions for each species (C. Brönmark, unpublished data). Periphyton was removed by brushing the flagging and was suspended in $0.5-1 \mathrm{~L}$ of water. From this algal suspension a $50-\mathrm{mL}$ sample was filtered onto a glass fiber filter (Whatman GF/C). The filter was preweighed and subsequently dried for $24 \mathrm{~h}$ at $60^{\circ} \mathrm{C}$ and re-weighed. To avoid pseudoreplication (sensu Hurlbert 1984), only the mean of the three flagging strands from each cage was used in the statistical analysis. Snail and periphyton data were natural log transformed to stabilize variances and analyzed with ANOVA (SAS 1988) blocking by groups of cages and controls; i.e., a group consisted of an exclosure, enclosure, and control from one of the five locations in each lake. Evaluation of treatment effects was based on the significance of 
TABLE 1. ANOVAs of mean snail dry biomass on plastic flags in pumpkinseed (Lepomis gibbosus) enclosures, exclosures, and cageless controls in Mann and Round lakes, Vilas County, Wisconsin, during 1986 and 1987. ENC $=$ Pumpkinseed Enclosures, EXC $=$ Pumpkinseed Exclosures, CONTROL $=$ Cageless Controls.

\begin{tabular}{|c|c|c|c|c|}
\hline Source of variation & $\mathrm{df}$ & MS & $F$ & $P$ \\
\hline \multicolumn{5}{|c|}{ Mann Lake } \\
\hline Treatment & 2 & 93.10 & 56.34 & .0001 \\
\hline Block & 4 & 3.05 & 1.85 & .2132 \\
\hline Error & 8 & 1.65 & & \\
\hline \multicolumn{5}{|l|}{ Contrasts } \\
\hline $\begin{array}{l}\text { EXC vs. ENC and } \\
\text { CONTROL }\end{array}$ & 1 & 98.18 & 59.41 & 0001 \\
\hline ENC vs. CONTROL & 1 & 88.01 & 53.26 & .0001 \\
\hline \multicolumn{5}{|c|}{ Round Lake } \\
\hline Treatment & 2 & 40.32 & 73.83 & .0001 \\
\hline Block & 4 & 2.05 & 3.75 & .0529 \\
\hline Error & 8 & 0.55 & & \\
\hline \multicolumn{5}{|l|}{ Contrasts } \\
\hline $\begin{array}{l}\text { EXC and CONTROL } \\
\text { vS. ENC }\end{array}$ & 1 & 76.73 & 140.50 & .0001 \\
\hline EXC vs. CONTROL & 1 & 3.91 & 7.15 & .0282 \\
\hline
\end{tabular}

contrasts. For example, in the high pumpkinseed lake we expected that enclosures would mimic controls; thus the contrast of exclosures vs. enclosures and controls tested whether high pumpkinseed treatments differed from that of no pumpkinseeds; the contrast of enclosures vs. controls tested how well the enclosures mimicked conditions in the natural environment. For periphyton, separate analyses were done for each lake and year, whereas for snails, 1986 and 1987 data were combined because snail biomass at the beginning of 1987 was a function of the biomass at the end of 1986 . To evaluate the effect of yellow perch on snail and periphyton biomass we compared perch enclosures with exclosures in Round Lake 1987, using ANOVA.

From each of the periphyton samples taken on 24 August 1987 (15 mo after the beginning of the experiments), a 100-mL aliquot was preserved with Lugol's solution. Algal density and taxonomic composition were determined with a compound microscope at $400 \times$ using a $1-\mathrm{mL}$ counting chamber. At least three complete transects of the chamber were counted, providing a minimum of 600 , but often well in excess of 2000 , cells per sample. Algal biovolume was computed by multiplying algal density by average cell volume for each taxon determined by measurement ( $n=100$ per taxon) and approximating the cell shape to standard geometric shapes. Cell volume was not corrected for cell walls or vacuole volumes. Patterns in algal assemblage structure were compared with principal components analysis, and differences among treatments in principal component scores along the two first PCA axes were analyzed using ANOVA.

To investigate how well flags mimicked natural macrophyte substrate, we collected one strand of Pota- mogeton robbinsii from each cage in Round Lake on 24 August 1987. Epiphytic algae were removed by shaking in jars, a method that removes the majority of epiphytic algae without contamination with macrophyte cells (Jones and Adams 1982). Leaf area was then determined by digitizing photocopies of the leaves.

Snail preference for the different periphyton assemblages found at high and low snail densities was determined in August 1987 by exposing the snails to periphyton on filter paper (Calow 1973). Periphyton from flagging in two adjacent cages in Round Lake (one exclosure and one enclosure) was suspended in water and filtered onto filter paper (Whatman GF/C, $4.7 \mathrm{~cm}$ diameter). Because we designed this experiment to assess snail preference for periphyton quality, i.e., species composition of the algal assemblage, we standardized periphyton dry mass in order to rule out quantity as a confounding variable. From each assemblage type we generated 10 filters. Dry masses of exclosure and enclosure filters did not differ $(8.0 \pm 0.7$ and $7.6 \pm 0.5$ $\mathrm{mg}$, respectively, $n=6, P>.05$, Mann-Whitney $U$ test). The remaining four filters were split and one half from an enclosure and one half from an exclosure were placed near the opposite edges of a plastic container $(9$ $\times 9 \times 6 \mathrm{~cm})$ under a thin layer of water. Containers were placed on a laboratory bench illuminated by daylight from a window and randomly rotated to control for position effects. After $2 \mathrm{~h}$ containers were filled with water and 20 Amnicola limosa (4-5 mm length, starved for $24 \mathrm{~h}$ ) were placed in the center of the container between the two filter papers. A pilot experiment revealed that the number of snails feeding on filters at any one time increased through $6 \mathrm{~h}$ after introduction and stabilized. Thus, snail positions were recorded after $6 \mathrm{~h}$.

\section{RESULTS \\ Response of snails to predation}

Pumpkinseed sunfish dramatically reduced biomass of snails on plastic flags (Fig. 1, Table 1). In Mann Lake (HDP) exclosures differed from enclosures/controls $(P$ $=.0001)$. Snail densities in controls were intermediate between exclosures and enclosures on most dates (Fig. 1) and higher in controls than enclosures $(P=.0001)$. The major decline in snail biomass in exclosures and

TABLE 2. ANOVAs of mean snail and periphyton dry biomass in perch enclosure and fish exclosure cages in Round Lake, Vilas County, Wisconsin, in 1987.

\begin{tabular}{lcccc}
\hline \hline $\begin{array}{l}\text { Source of } \\
\text { variation }\end{array}$ & df & MS & $F$ & $P$ \\
\hline \multicolumn{5}{c}{ Snail biomass } \\
Treatment & 1 & 0.00 & 0.00 & .994 \\
Error & 6 & 0.56 & & \\
\multicolumn{5}{c}{ Periphyton biomass } \\
Treatment & 1 & 0.02 & 0.21 & .661 \\
Error & 6 & 0.08 & & \\
\hline
\end{tabular}


Mann Lake (HDP)

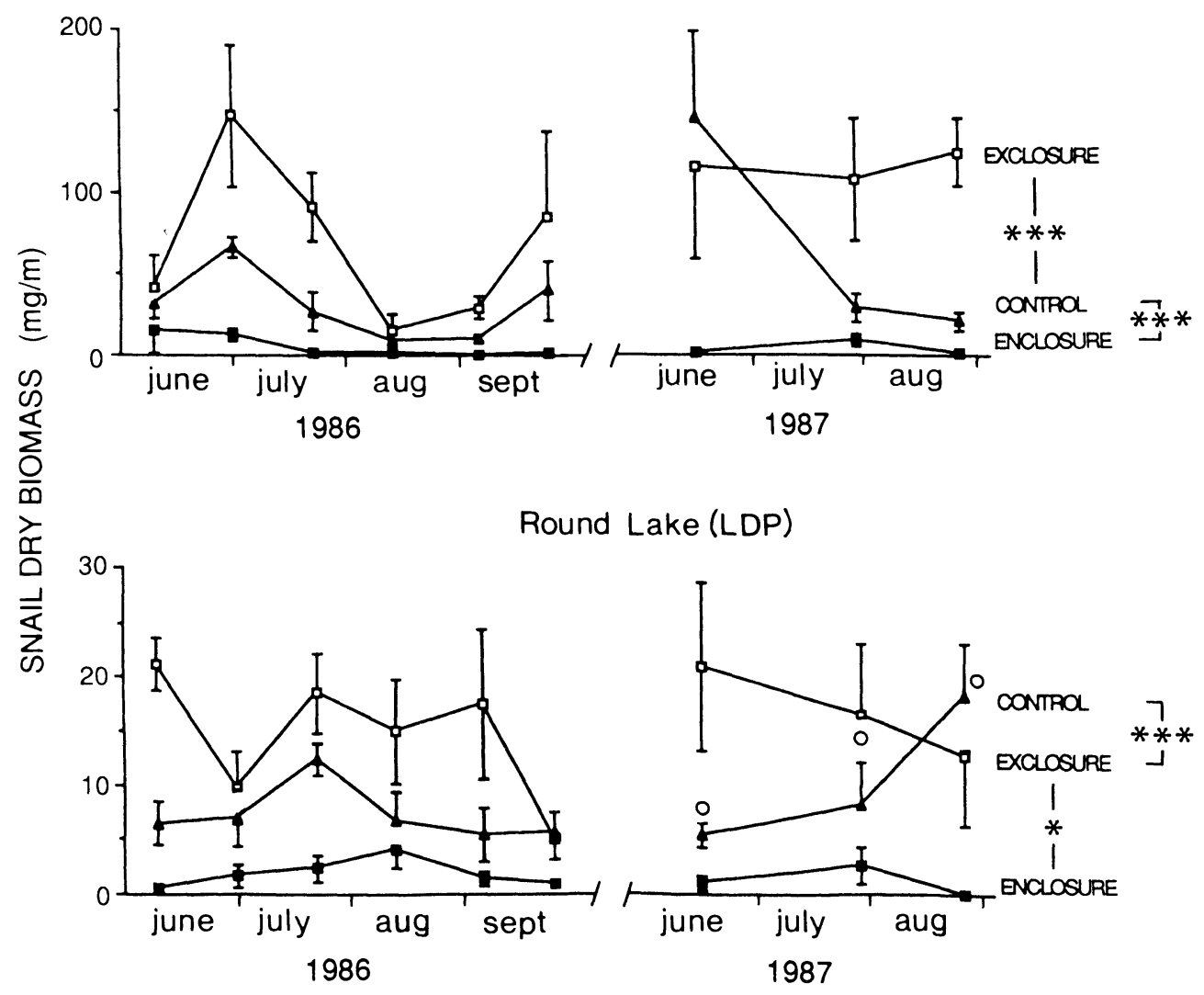

FIG. 1. Snail dry biomass on plastic flagging placed in pumpkinseed (Lepomis gibbosus) enclosures, exclosures, and cageless controls $(N=5)$ in Mann (high density of pumpkinseeds, HDP) and Round (low density of pumpkinseeds, LDP) lakes, Vilas County. Wisconsin. Open circles $(O)$ in Round Lake 1987 denote mean snail biomass in yellow perch (Perca flavescens) enclosures $(N=3)$. Vertical bars denote \pm 1 SE. Note difference in scale of $Y$ axis between lakes. Asterisks show significance of time $\times$ treatment contrasts for the comparisons between exclosures vs. enclosures/controls and enclosures vs. controls in Mann Lake and between exclosures/controls vs. enclosures and exclosures vs. controls in Round Lake. ${ }^{*} P<.05,{ }^{* * *} P<$ .001 .

controls in Mann Lake in July-August in 1986 was due to a generation shift in the two dominant snail species, Amnicola limosa and Marstonia lustrica. In Round Lake, with low pumpkinseed density, snail density was higher in exclosure/controls than in enclosures $(P=$ .001 ). As in Mann Lake, snail densities in Round Lake controls were intermediate between exclosures and enclosures, whereas exclosures differed from controls $(P$ $=.0282)$. Snail biomass did not differ between yellow perch cages and exclosures in Round Lake (Fig. 1, Table 2), suggesting yellow perch had no impact on snails.

Other potential periphyton grazers, such as amphipods, trichopterans, and chironomids, occurred occasionally on the flagging, but these organisms were far less abundant than snails. A leptocerid trichopteran was an exception, for it occurred in high densities on flagging in Mann Lake in early June 1986. However, 3 wk later all larvae had pupated and emerged. Further, its density in early June was not related to treatment (ANOVA, $F_{2.12}=1.351, P=.296$ ), indicating that differences between treatments in periphyton biomass could not have been an effect of grazing by this caddisfly larva.

\section{Response of periphyton to grazing}

Dry mass. - We predicted that reduced snail density in enclosures should lead to high periphyton biomass as compared to exclosures where grazing pressure should be high (Fig. 2). Mann Lake (HDP) controls should parallel enclosures, whereas Round Lake (LDP) cageless controls should approach exclosures. These expected similarities would depend upon how well we mimicked actual predation pressure in our lakes by excluding and enclosing pumpkinseed sunfish.

Periphytic algae readily colonized plastic flagging (Fig. 2). In Mann Lake (HDP) in both years periphyton dry biomass was greater, as predicted, in enclosure/controls than in exclosures (Fig. 2, Table 3). Controls paralleled enclosures in 1986, whereas in 1987 the pattern was less clear, yielding a significant difference between 
Mann Lake (HDP)
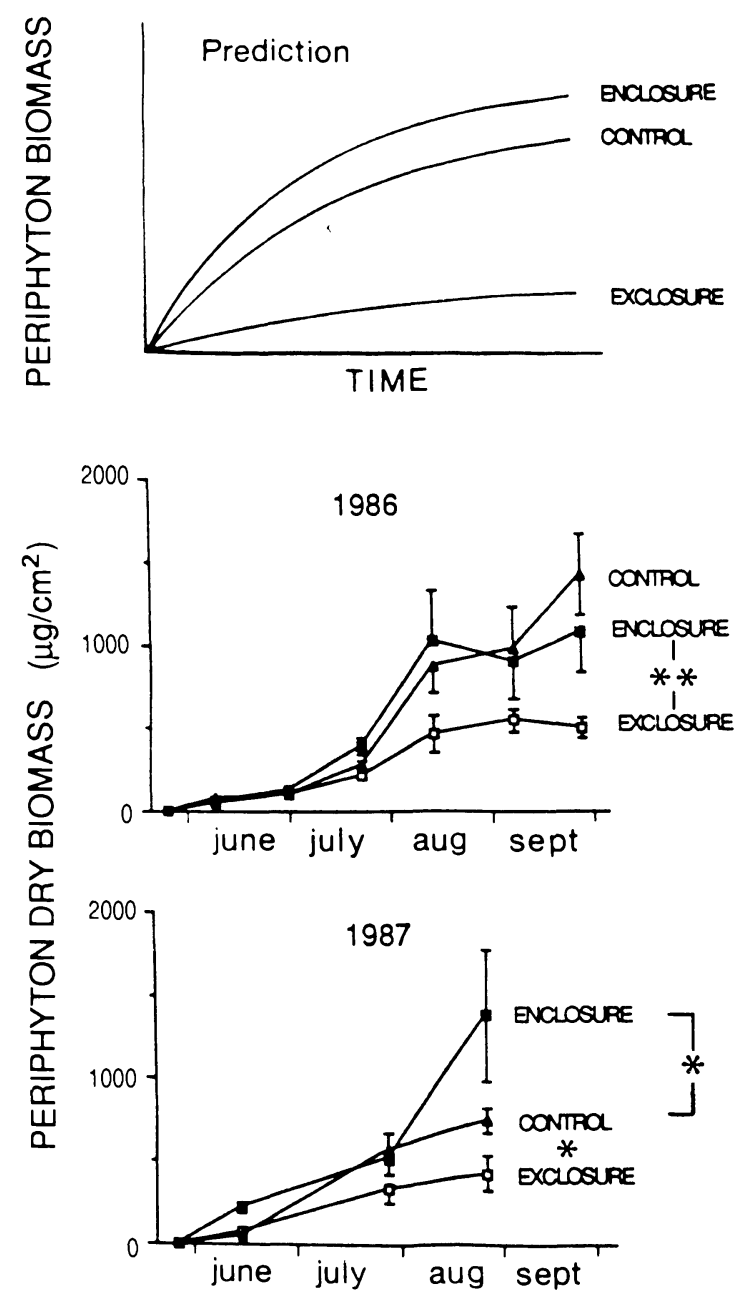

Round Lake (LDP)
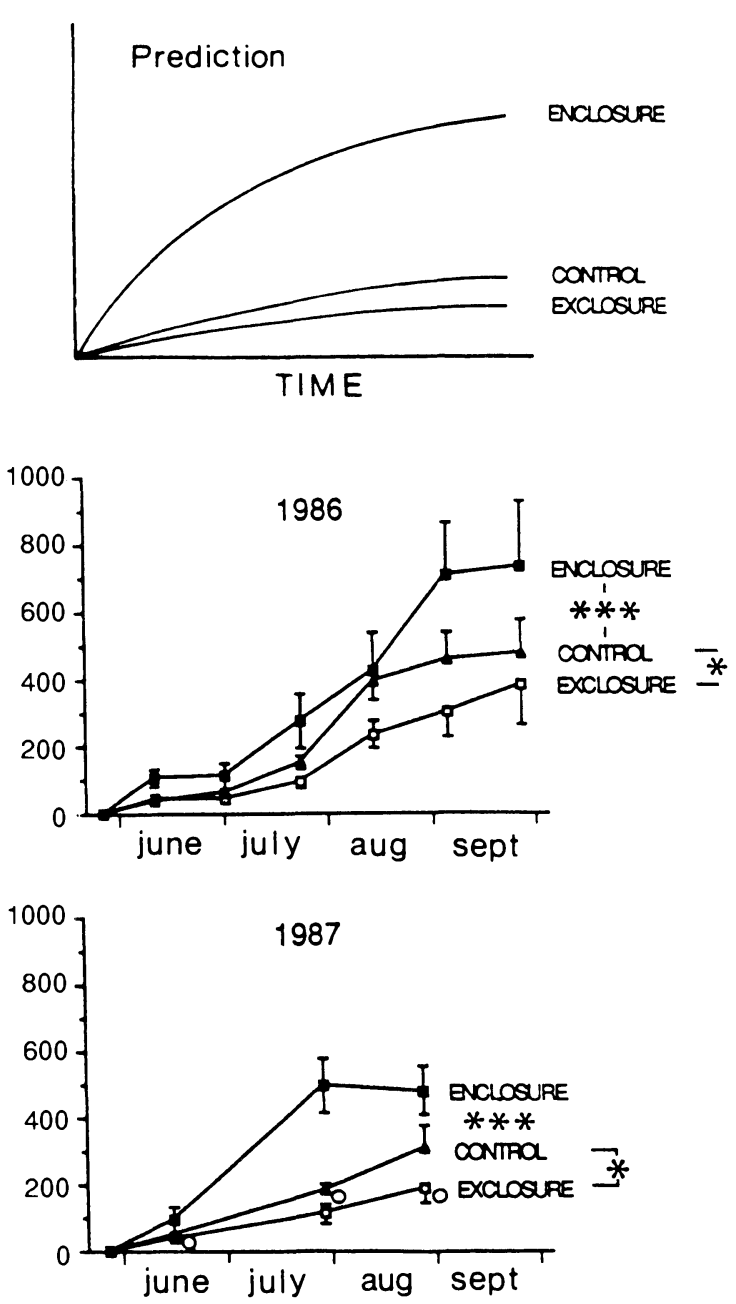

FIG. 2. Periphyton dry biomass from plastic flags placed in pumpkinseed (Lepomis gibbosus) enclosures, exclosures, and cageless controls $(N=5)$ in Mann (HDP) and Round (LDP) lakes, Vilas County, Wisconsin. The top two graphs provide a priori predictions from cascading trophic interaction theory. Open circles (O) in Round Lake 1987 denote mean periphyton biomass in yellow perch cages $(N=3)$. Vertical bars denote \pm 1 SE. Note difference in scale of $Y$ axis between lakes. Asterisks show significance of treatment contrasts for the comparisons between exclosure vs. enclosures/controls and enclosures vs. controls in Mann Lake and between exclosures/controls vs. enclosures and exclosures vs. controls in Round Lake. ${ }^{*} P<.05$, ** $P<.01, * * * P<.001$.

controls and enclosures. In Round Lake (LDP), periphyton dry biomass was higher in enclosures than in exclosure/controls and higher in controls than in exclosures (Fig. 2, Table 4). Periphyton biomass in yellow perch cages in Round Lake mimicked biomass in pumpkinseed exclosures (Fig. 2, Table 2).

A negative, nonlinear relationship occurred between mean snail dry biomass (averaged over all dates) and final periphyton dry biomass. The data were log transformed to straighten the relationship and subjected to regression analysis. The relationship was significant for both years in Round Lake (1986: $F_{1,13}=5.172, P=$ $\left..041 ; 1987: F_{1.13}=4.562, P=.052\right)$ and for the 2 nd $\mathrm{yr}$ in Mann Lake (1986: $F_{1,13}=2.773, P=.120 ; 1987$ : $\left.F_{1.13}=7.311, P=.018\right)$.

Species composition. - Taxonomic composition of the periphyton assemblage differed between lakes, but the same general response to changes in grazing pressure occurred in both lakes (Figs. 3 and 4, Tables 5 and 6). When grazing pressure was low, as in enclosures, filamentous algae and large diatoms dominated. In Mann Lake, enclosures separated from exclosures and controls along the first principal component axis, being dominated by the filamentous Fragilaria spp. (diatom) and Oedogonium spp. (green alga) and the large, solitary diatom Epithemia spp. Enclosures in 
TABLE 3. ANOVA of mean periphyton biomass on plastic flagging in pumpkinseed (Lepomis gibbosus) enclosures (ENC). exclosures (EXC), and cageless controls (CONTROL) in Mann Lake, Vilas County, Wisconsin, in 1986 and 1987.

\begin{tabular}{lcccc}
\hline \hline \multicolumn{1}{c}{ Source of variation } & df & MS & $F$ & $P$ \\
\hline \multicolumn{4}{c}{ Mann Lake 1986} \\
Treatment & 2 & 2.87 & 6.75 & .0192 \\
Block & 4 & 0.05 & 0.12 & .9712 \\
Error & 8 & 0.43 & & \\
$\quad$ Contrasts & & & & \\
EXC vs. ENC and & & & & \\
$\quad$ CONTROL & 1 & 5.74 & 13.50 & .0063 \\
ENC vs. CONTROL & 1 & 0.001 & 0.000 & .9587 \\
\multicolumn{2}{c}{ Mann Lake 1987 } & & \\
Treatment & 2 & 3.51 & 9.58 & .0075 \\
Block & 4 & 0.80 & 2.19 & .1607 \\
Error & 8 & 0.37 & & \\
$\quad$ Contrasts & & & & \\
EXC vs. ENC and & & & & \\
$\quad$ CONTROL & 1 & 3.48 & 9.49 & .0151 \\
ENC vs. CONTROL & 1 & 3.55 & 9.68 & .0144 \\
\hline
\end{tabular}

Round Lake separated from exclosures and controls by having a high relative biovolume of large solitary diatoms, such as Cymbella spp., Gomphonema spp., Rhopalodia spp., and Epithemia spp. The dominant filamentous algae in Round Lake enclosures were $\mathrm{Mou}$ geotia spp. (green algae) and Fragilaria spp.

In exclosures, with high grazing pressure, the periphyton assemblage was dominated, in both lakes, by the colonial, filamentous blue-green alga Gloeotrichia spp. A colonial green alga, Coleochaete spp., also increased in relative abundance at high grazing pressures, whereas filamentous diatoms, green algae, and large solitary diatoms were reduced in abundance. In Mann Lake, in addition, small diatoms and Cocconeis spp. increased in relative abundance.

Algal assemblages in cageless controls and exclosures in Round Lake (LDP) were quite similar and did not separate along either axis 1 or 2. Cageless controls in Mann Lake (HDP) were intermediate between enclosures and exclosures along the first principal component axis, whereas they separated out along the second axis by having a higher abundance of Epithemia spp. and Cocconeis spp. The large, solitary diatom Epithemia spp. was dominant in the Mann Lake cageless controls.

Epiphyton on P. robbinsii.-Epiphytic biomass on the leaves of $P$. robbinsii showed a positive relationship to algal biomass on flags on 24 August 1987 ( $Y=40.01$ $+1.01 X, r=0.85, N=15, P<.001)$. The slope (1.01) was remarkably close to 1 , suggesting that flags closely mimicked natural substrates with regard to periphyton biomass. Further, epiphyton biomass in enclosures was higher than in exclosures (ANOVA, $F=7.23, P=.02$ ), whereas controls were intermediate between, and did not differ from, enclosures and exclosures.
TABLE 4. ANOVA of mean periphyton biomass in Round Lake, Vilas County, Wisconsin, in 1986 and 1987.

\begin{tabular}{|c|c|c|c|c|}
\hline Source of variation & $\mathrm{df}$ & MS & $F$ & $P$ \\
\hline \multicolumn{5}{|c|}{ Round Lake 1986} \\
\hline Treatment & 2 & 4.82 & 14.65 & .0021 \\
\hline Block & 4 & 2.21 & 6.71 & .0113 \\
\hline Error & 8 & 0.33 & & \\
\hline \multicolumn{5}{|l|}{ Contrasts } \\
\hline \multicolumn{5}{|l|}{ EXC and CONTROL } \\
\hline EXC vs. CONTROL & 1 & 2.13 & 6.47 & .0345 \\
\hline \multicolumn{5}{|c|}{ Round Lake 1987} \\
\hline Treatment & 2 & 4.39 & 19.43 & .0008 \\
\hline Block & 4 & 0.44 & 1.93 & .1987 \\
\hline Error & 8 & 0.23 & & \\
\hline \multicolumn{5}{|l|}{ Contrasts } \\
\hline $\begin{array}{l}\text { EXC and CONTROL } \\
\text { vS ENC }\end{array}$ & 1 & 7.41 & 3280 & 0004 \\
\hline EXC vs. CONTROL & 1 & 1.37 & 6.06 & .0392 \\
\hline
\end{tabular}

Preference experiment. - After $6 \mathrm{~h}$, more Amnicola limosa colonized filter papers with periphyton from enclosures (low grazing pressure) than periphyton from exclosures (Fig. 5, Kruskal-Wallis, $N=7, P<.01$ ). Because our experiment used algae from enclosures and exclosures collected on 24 August 1987, the same day assemblage composition was quantified, we pre-

TABLE 5. Factor loadings for algal taxa in the three treatments in Mann and Round lakes and percentage variance accounted for by the principal component axes.

\begin{tabular}{|c|c|c|}
\hline & \multicolumn{2}{|c|}{ Principal component } \\
\hline & 1 & 2 \\
\hline \multicolumn{3}{|c|}{ Mann Lake } \\
\hline Variance explained (\%) & 38.5 & 27.8 \\
\hline Eigenvalues & 2.69 & 1.95 \\
\hline \multicolumn{3}{|l|}{ Algae } \\
\hline Coleochaete & 0.87 & 0.26 \\
\hline Gloeotrichia & 0.76 & 0.06 \\
\hline Small diatoms & 0.69 & 0.27 \\
\hline Fragilaria & -0.57 & 0.58 \\
\hline Epithemia & -0.44 & -0.83 \\
\hline Cocconneis & 0.42 & -0.83 \\
\hline Oedogonium & -0.45 & 0.32 \\
\hline \multicolumn{3}{|c|}{ Round Lake } \\
\hline Variance explained (\%) & 61.7 & 12.4 \\
\hline Eigenvalues & 6.79 & 1.37 \\
\hline \multicolumn{3}{|l|}{ Algae } \\
\hline Gloeotrichia & -0.93 & 0.23 \\
\hline Cymbella & 0.93 & 0.24 \\
\hline Gomphonema & 0.92 & 0.25 \\
\hline Epithemia & 0.90 & 0.08 \\
\hline Fragilaria & 0.88 & 0.31 \\
\hline Synedra & 0.88 & 0.06 \\
\hline Rhopalodia & 0.84 & -0.29 \\
\hline Melosira & 0.80 & 0.23 \\
\hline Coleochaete & -0.51 & 0.33 \\
\hline Mougeotia & 0.50 & -0.82 \\
\hline Small diatoms & 0.02 & 0.41 \\
\hline
\end{tabular}


TABLE 6. Comparison of principal component scores for the three treatments (ENC = Pumpkinseed [Lepomis gibbosus] Enclosures, $\mathrm{EXC}=$ Pumpkinseed Exclosures, $\mathrm{CC}=$ Cageless Controls) in Mann and Round lakes, using ANOVA and contrasts for pairwise comparisons. Underlined comparisons do not differ $(P>.05)$.

A. Comparison of treatments

Mean principal component score

\begin{tabular}{crr} 
Treatment & Axis 1 & Axis 2 \\
\cline { 2 - 3 } Mann Lake & & 0.82 \\
Enclosures & -0.99 & 0.31 \\
Exclosures & 0.99 & 1.13 \\
Cageless controls & 0.09 & -0.30 \\
Round Lake & & 0.06 \\
Enclosures & 1.25 & 0.26
\end{tabular}

B. ANOVA results

\begin{tabular}{|c|c|c|c|c|c|c|c|c|}
\hline \multicolumn{2}{|c|}{ Comparisons } & $\mathrm{df}$ & MS & $F$ & $P$ & \multicolumn{3}{|c|}{ Pairwise comparisons } \\
\hline \multicolumn{9}{|c|}{ Mann Lake } \\
\hline \multirow[t]{2}{*}{ Axis 1} & Treatment & 2 & 4.92 & 14.21 & .001 & ENC & EXC & $\mathrm{CC}$ \\
\hline & Error & 12 & 0.35 & & & & & \\
\hline \multirow[t]{2}{*}{ Axis 2} & Treatment & 2 & 5.14 & 16.54 & .001 & ENC & EXC & $\mathrm{CC}$ \\
\hline & Error & 12 & 0.31 & & & & & \\
\hline \multicolumn{9}{|c|}{ Round Lake } \\
\hline \multirow[t]{2}{*}{ Axis 1} & Treatment & 2 & 6.09 & 39.96 & .001 & ENC & $\underline{E X C}$ & $\mathrm{CC}$ \\
\hline & Error & 12 & 0.15 & & & & & \\
\hline \multirow[t]{2}{*}{ Axis 2} & Treatment & 2 & 0.40 & 0.36 & .70 & & & \\
\hline & Error & 12 & 1.10 & & & & & \\
\hline
\end{tabular}

sume that Amnicola were choosing between these two assemblages. If so, Amnicola preferred filamentous algae and large diatoms over colonial green and bluegreen algae.

\section{Discussion}

\section{Snail responses to predation}

Pumpkinseed sunfish reduced snail biomass on flags in cages in the two lakes. We are convinced this result derives from direct predation, though it could be argued that a behavioral habitat shift induced by presence of predators (cf. e.g., Power 1987) may yield similar results. However, data from core samples (Klosiewski 1991) indicate that pumpkinseeds have directly reduced snails. In contrast, Osenberg (1989) argued that pumpkinseed predation did not limit snail biomass in southern Michigan lakes. He found that exclusion of pumpkinseeds had a minor effect on most snail taxa, though the most vulnerable species (large, thin-shelled) did increase. However, because the density of large, molluscivorous pumpkinseeds in Osenberg's lake was low $\left(0.01 \mathrm{fish} / \mathrm{m}^{2}\right)$ and his experiment lasted only $93 \mathrm{~d}$, absence of a documented predation effect can be reconciled with our results. Excluding predators in a system where the ambient predator density is low would be expected to yield no change, as we documented in Round Lake (LDP), where snail densities in cageless controls were similar to exclosures.
Furthermore, time lags of several generations would be expected in any predator-exclusion experiment; in our work, Physella integra did not reach high densities in exclosures until the second summer in Mann Lake (HDP) (Klosiewski 1991). Exclusion of another molluscivorous sunfish, the redear sunfish (Lepomis microlophus), during a 16-mo experiment resulted in 26 fold increases in gastropod biomass (Martin et al. 1992). When the central mudminnow Umbra limi was combined with Lymnaea elodes, egg masses and juvenile snails were reduced (Brown and DeVries 1985). Density of snails increased in predator exclosures as compared to cageless controls in work by Brönmark (1988). Hence, not all experimental manipulations provide similar conclusions.

These somewhat contradictory results are an extension of the continuing controversy over whether fish predation affects density, biomass, size structure, and/ or species composition in benthic macroinvertebrate communities in freshwater lentic and lotic systems. In some experiments fish predation has influenced benthic macroinvertebrate communities (Ball and Hayne 1952, Crowder and Cooper 1982, Gilinsky 1984, Morin 1984, Gilliam et al. 1989), whereas in other experiments fish seem to have no impact (Thorp and Bergey 1981a, b, Allan 1982, Hanson and Leggett 1986, Reice and Edwards 1986). Changes in total biomass or density of macroinvertebrates may be an inappropriate 
Mann Lake (HDP)

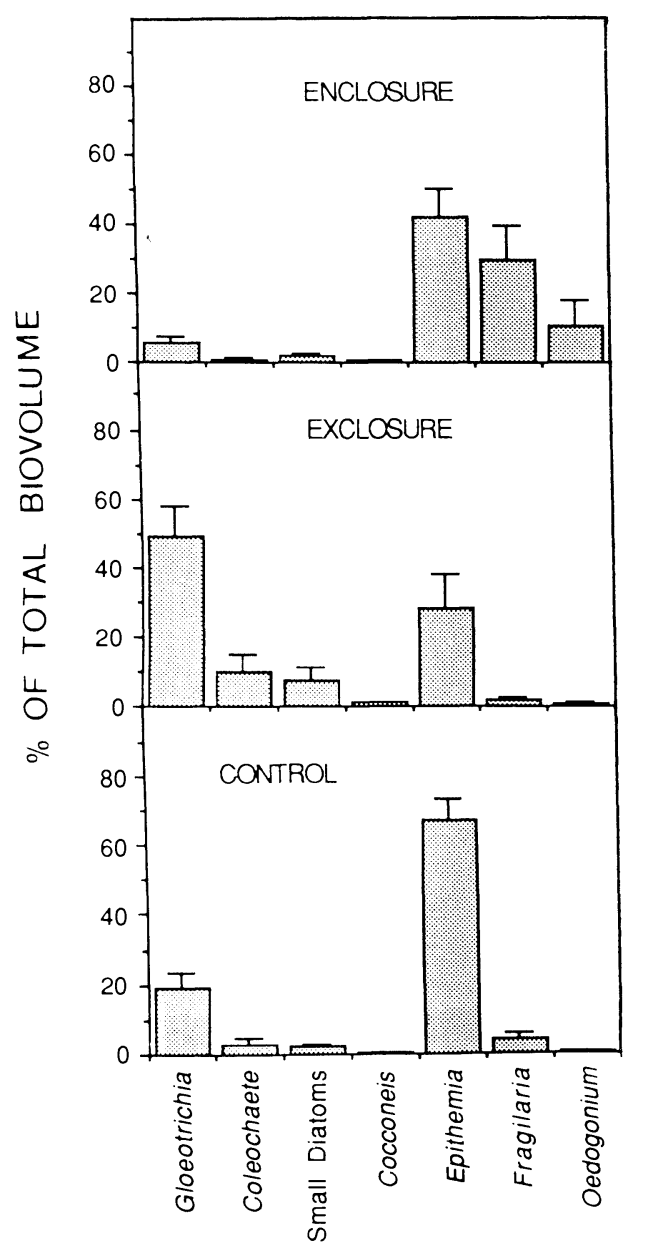

Round Lake (LDP)

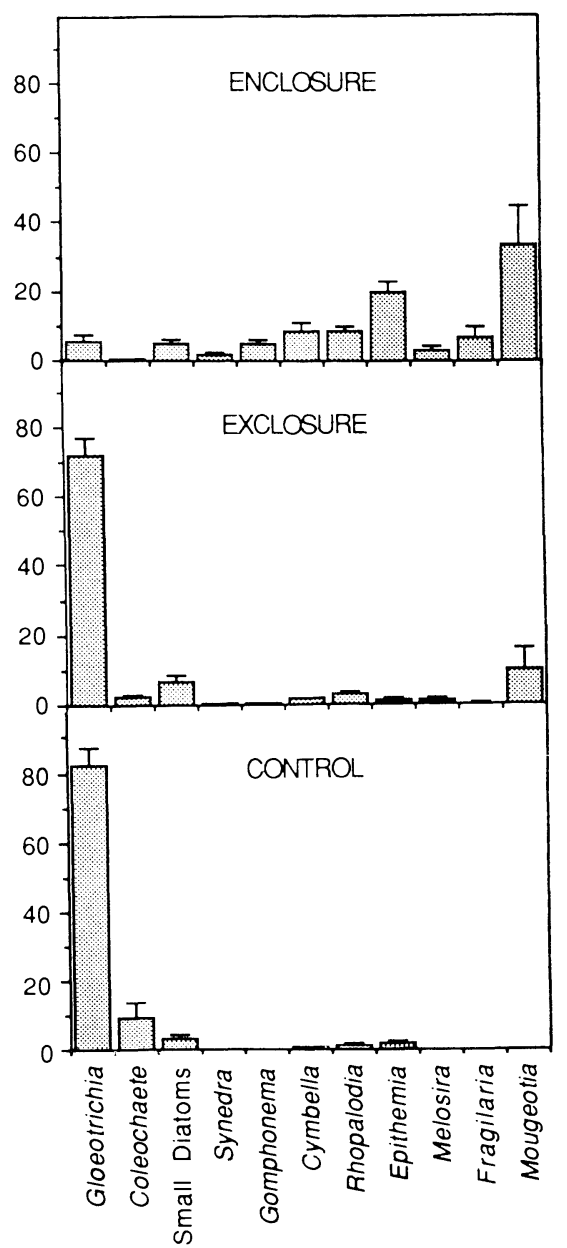

FIG. 3. Relative biovolume of periphytic taxa in pumpkinseed (Lepomis gibbosus) enclosures, exclosures, and cageless controls in Mann and Round lakes in Vilas County, Wisconsin, 24 August 1987. Data are means and 1 SE.

response parameter (Crowder and Cooper 1982, Mittelbach 1988). Because predation is size specific, juvenile sunfish can dramatically reduce certain size classes, whereas others may be unchanged (Mittelbach 1988). Most studies examining how fish predation influences benthic macroinvertebrates do so by introducing fish to previously fishless systems, i.e., not in systems where predator and prey had co-occurred for any length of time (Thorp 1986, Mittelbach 1988). In our study, however, we manipulated fish densities in two lakes with historically high and low densities of pumpkinseed sunfish. The congruence of the results from our two systems increases the significance of our findings. As such, we are convinced that, via direct predation, pumpkinseed sunfish dramatically reduced snail densities and modified snail assemblages in cage experiments in Mann and Round lakes, Wisconsin.

However, in both lakes, we failed to mimic closely the lake predatory environment (cageless controls) with our treatments (enclosures/exclosures). With our design, enclosures in Mann Lake (HDP) and exclosures in Round Lake (LDP) should have mimicked their respective cageless controls. In Mann Lake (HDP), high pumpkinseed densities should reduce snail densities in both controls and enclosures. Conversely, in Round Lake (LDP), snails should not be subjected to predation in cageless controls or exclosures.

That both treatments differed from their respective controls is not surprising. In Mann Lake (HDP), enclosures contained slightly higher snail biomass than cageless controls. Pumpkinseed densities in enclosures were chosen after preliminary density estimates in Mann Lake during summer 1985 . However, low oxygen conditions in winter 1985-1986 reduced the resident pumpkinseed densities in the lake to levels below what we added into enclosures. In addition, although dif- 


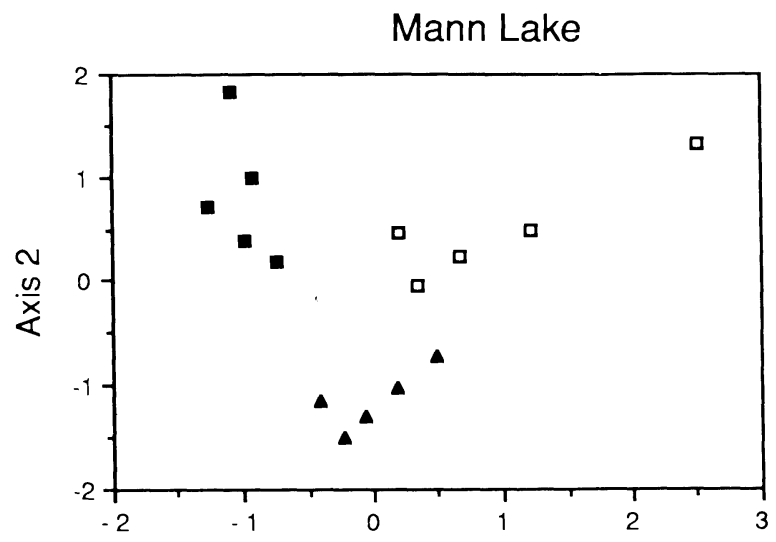

Axis 1

- Enclosures

- Exclosures

- Cageless Controls

\section{Round Lake}

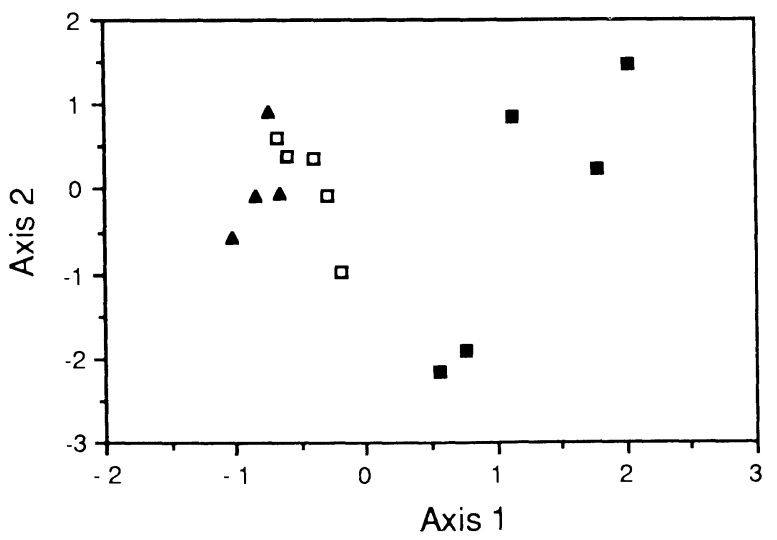

FIG. 4. Principal components analyses of periphytic taxa in pumpkinseed (Lepomis gibbosus) enclosures, exclosures, and cageless controls in Mann and Round lakes in Vilas County, Wisconsin, 24 August 1987

ferences in snail biomass were significant, absolute differences between controls and enclosures were quite small (Fig. 1). In Round Lake (LDP), exclosures supported higher snail biomass than cageless controls, suggesting that predators resident in the lake may have reduced cageless control biomass relative to exclosures. Yellow perch, which include snails in its diet (Hanson and Leggett 1986), had a high density in Round Lake, but the similarity between yellow perch cages and exclosures indicates that yellow perch was not responsible for the decrease in snails. It is possible, however, that the low density of pumpkinseeds found in Round Lake was sufficient to cause a reduction in snail biomass in cageless controls relative to exclosures. As with Mann Lake, absolute differences were small (Fig. 1), suggesting our ability to mimic the lake environment in these two lakes was reasonably good, though not perfect.
Periphyton responses

Given the substantial reduction in snail densities due to predation, we expected a concomitant positive response in biomass accumulation of periphytic algae. In exclosures in both lakes, snails reduced periphyton biomass, whereas in enclosures, periphyton biomass increased by 3-5 times. Grazing effects have been explored in a variety of laboratory and field experiments. Manipulations of snail densities in laboratory stream channels or on natural substrates in streams and lakes reveal that snails can greatly reduce the biomass of periphyton (see review in Brönmark 1989). Periphyton biomass in cageless controls in Mann Lake (HDP) 1986 did not differ from enclosures, suggesting that grazing pressure in enclosures closely mimics actual grazing pressure in the lake. Cageless controls differed from exclosures in Round Lake as expected from differences in snail densities. Yellow perch apparently had no effect on snail/periphyton interactions because the biomass on flags in perch cages was almost identical to the biomass on exclosure flags.

An alternative explanation to the increase in periphyton biomass in the presence of pumpkinseed sunfish may be that fish enhance nutrient turnover rates (cf. Threlkeld 1987). Nutrient concentrations contribute to the control of periphyton assemblages (Müller 1983, Wetzel 1983); an increase in nutrient availability due to fish excretion or defecation may be expected to enhance algal productivity. However, by comparing periphyton biomass in pumpkinseed enclosures with yellow perch enclosures we can reject the nutrient-enhancement hypothesis. Periphyton biomass in yellow perch cages was much lower than in pumpkinseed enclosures and almost identical to exclosures. Thus, effects on periphyton can be attributed to changes in snail grazing pressure, supported also by the generally neg-

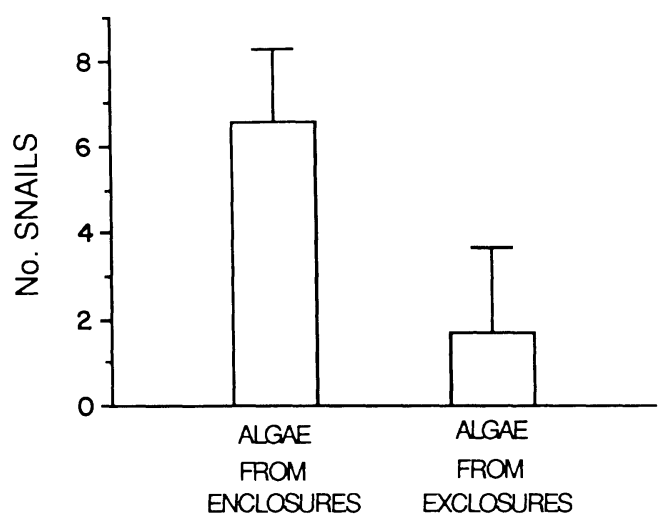

FIG. 5. Number of Amnicola limosa on filter paper with periphyton from pumpkinseed sunfish (Lepomis gibbosus) enclosures or exclosures collected near the experiment's end ( 24 August 1987) from Round Lake, Vilas County, Wisconsin. Data are means and $1 \mathrm{SD}$. 
ative relation between snail biomass and periphyton biomass.

In a review of field experiments, Thorp (1986) pointed out the lack of studies demonstrating more than a transitory effect. Not one of these studies was performed over several years or generations of the dominant prey species, and thus it is unclear whether changes caused by predators are nontransitory or only a shortterm disturbance effect.' Our study, which was run over two consecutive seasons involving at least two generations of snails, clearly shows that predatory effects of pumpkinseed sunfish are not transitory, simply because patterns of periphyton biomass were repeated during the second summer.

Many studies on snail grazing effects have demonstrated a shift in species composition of periphyton assemblages (reviewed in Brönmark 1989). In general, larger overstory species, such as stalked diatoms and filamentous species, are more susceptible to grazing and are reduced at high grazing pressures, whereas small, tightly adherent species increase in relative abundance when the periphyton assemblage is subject to snail herbivory. In enclosures where the grazing pressure was low. the periphyton assemblage was dominated by filamentous green algae and large diatoms which often are attached to substrate with long mucus stalks or enclosed in mucus tubes. In exclosures, small, adnate diatoms and Coleochaete, a green alga that grows with a prostrate disk-like thallus, predominated. In addition, the filamentous, colonial blue-green algae Gloeotrichia increased as grazing pressure increased. Studies on epiphyton on plants in a Canadian lake similarly has shown a dominance of Gloeotrichia pisum under high grazing pressure by snails (Cattaneo 1983, Cattaneo and Kalff 1986). Several blue-green algae are known to be toxic to grazers (e.g., Porter 1977) and Gloeotrichia colonies are further protected by a tough mucopolysaccharide sheath (Cattaneo 1983). The large size of Gloeotrichia colonies, up to several millimetres, may also impede ingestion by snails.

General food chain theory (e.g., Fretwell 1987) predicts that the vulnerability of a species is correlated positively with its competitive ability, i.e., in the absence of grazing, periphyton assemblages should be dominated by highly competitive but vulnerable species. At low grazing/high biomass when cell layers are thick, both filamentous forms and those attached to the substrate with mucus stalks dominate. These larger overstory species have an advantage in competition for light and nutrients as compared to small species more closely associated with the substrate. Of course, this assemblage of loosely attached filamentous and stalked species are highly vulnerable to grazing and should decline as grazing pressure increases, just what occurred in our exclosures. When grazing pressure increases, assemblages should shift to competitively inferior but less vulnerable species. Being small and adherent. such as Cocconeis, is one way of achieving invulnerability to grazing; other species, such as Gloeotrichia, may be toxic or otherwise unpalatable to grazers. Differences in periphyton palatability due to grazing also were clearly demonstrated in the choice experiment where snails preferred periphyton from treatments subjected to low grazing pressure. Snails probably do not graze selectively on individual algal cells; instead they are more likely to choose patches with preferred algae (Lowe and Hunter 1988).

Grazing by snails also may affect the seasonal species succession of a periphyton assemblage. Succession generally proceeds from a monolayer assemblage dominated by small, adnate diatoms to a more structurally complex community with stalked diatoms and short filamentous algae to a final stage where the assemblage is dominated by long, filamentous algae (Steinman et al. 1987). Exclusion of snails, i.e., a decrease in the grazing pressure, halts succession at an intermediate stage (Cattaneo 1983). In our study, however, the successional process was reversed, rather than halted, reverting to early seral stages characterized by small, tightly adhered algae.

\section{Relation to food chain theory}

HSS theory predicts that in a food chain with three trophic levels, as in the pumpkinseed-snail-algae case, the main structuring force acting on predators will be competition for food resources (i.e., herbivore populations). Herbivores will be regulated by predators and kept at such low densities that primary producers will be unaffected by herbivory. Plants, in turn, will be limited by competition for resources (e.g., nutrients, space). Menge and Sutherland (1987; hereafter called MS) recently presented a formalized version of their earlier, alternative model for community regulation (Menge and Sutherland 1976), based on their knowledge of the interactions occurring in the marine intertidal. In addition to competition, abiotic disturbance and recruitment were included. Under benign conditions at high recruitment, MS predicted competition to be the most important factor at the top trophic level, whereas the herbivore level should be limited by predators. This is in correspondence with the predictions from HSS. However, for the basal trophic level, MS predicted that herbivory should limit primary producers, whereas HSS suggested that it depends on the number of trophic levels in the food chain. In a food chain with four levels, herbivory should regulate primary producers, whereas in a food chain with three levels producers will be resource limited. The discrepancies between these two models is due to a high degree of omnivory, assumed by MS. Without omnivory, predictions are identical. The model of Lodge et al. (1987), which encompasses the herbivore level only, also predicted that herbivores, in this case snails, will be regulated by predation in large lakes where physical disturbance is limited.

Densities of pumpkinseed sunfish, and thus preda- 
tion pressure on snails, differ in our lakes. Regulation of pumpkinseed density within these lakes is a complex process involving predation, competition, and abiotic disturbance. Both lakes have piscivorous fish, but the piscivore assemblage is more diverse and has a higher total abundance in Round Lake (seven species; 0.191 individuals $/ \mathrm{m}$ of shoreline as determined from night electrofishing five randomly chosen $50-\mathrm{m}$ transects in summer 1987; Klosiewski 1991) as compared to Mann Lake (two species; 0.047 individuals/m of shoreline). In addition to direct effects, presence of predators also may increase the intensity of competition between juvenile bluegill and pumpkinseed sunfish after their behavioral habitat shifts in response to predators (Mittelbach 1984, 1988, Mittelbach and Chesson 1987). Given that Mann Lake is more susceptible to winterkill and exposed to higher fishing pressure, we speculate that it had a piscivore population insufficiently abundant to affect pumpkinseeds, resulting ili a system with effectively three trophic levels (cf. Fretwell 1987). Conversely, Round Lake, with an abundance of piscivores, conceivably dense enough to control pumpkinseeds, could be regarded as a four-trophic-level system.

In our food chain, the highly specialized pumpkinseed sunfish feeds almost exclusively on snails, with the remainder of its diet consisting of other macroinvertebrates (Sadzikowski and Wallace 1976, Mittelbach 1984, Osenberg and Mittelbach 1990). Without omnivory, this food chain should be regulated as predicted by HSS theory. Reductions in snail density by pumpkinseeds and concomitant increases in periphyton biomass conform to HSS theory. Predation by redear sunfish likewise reduced snails and increased periphyton biomass (Martin et al. 1992). This same general pattern occurred as well in an experiment with a more general macroinvertebrate predator (tench, Tinca tinca; C. Brönmark, unpublished data). Abundant periphyton on cobole substrates from the littoral zone in northern Wisconsin lakes flourished because crayfish predators in this habitat reduce snail abundance (Weber and Lodge 1990). Periphyton increased in yellow perch enclosures due to a reduction of grazing amphipods and chironomids (Mazumder et al. 1989). Fish predation had a distinct effect on a stream community with four trophic levels, reducing smaller insect predators and thus allowing grazing chironomids to increase in density to levels where algal standing crops were much reduced (Power 1990). In addition, in marine intertidal systems the importance of cascading trophic interactions in benthic food chains has been well documented in some habitats (sea otter-sea urchinkelp: Estes and Palmisano 1974, Simenstad et al. 1978, Duggins 1980; man-snails-algae: Moreno et al. 1984). In contrast, Osenberg (1989) found that predation by pumpkinseeds did not limit snail densities in an oligotrophic lake. Instead, addition of phosphorus in a field experiment showed that both snails and algae were limited by resource availability. This is in agreement with McQueen et al. (1986), who suggested, after studying freshwater pelagic food chains, that bottom-up forces (resource limitation) are the dominant structuring forces at lower trophic levels and weaken toward the top of the food chain. Recent theoretical contributions (e.g., Oksanen et al. 1981, Persson et al. 1988, Leibold 1989) argue that community structure is driven by interactions between top-down and bottom-up forces, with nutrients setting ultimate limits on productivity and number of trophic levels. Although the results from our study and others point in the direction of top-down interactions regarding benthic food chains, long-term studies where both predation and resource levels (nutrients) are manipulated could provide additional insight into the dynamics of benthic food chains. Clearly, however, in our systems, top-down effects played an extremely important role in regulating community structure.

\section{ACKNOWLEDGMENTS}

During part of this study C. Brönmark was supported by an Ohio State University post-doctoral fellowship, funded through the Graduate School, The Ohio State University. Support from the National Science Foundation (to R. A. Stein, BSR 850772) and from the Swedish Natural Science Research Board and the Swedish Institute (to C. Brönmark) is appreciated. The field work was carried out at the Trout Lake Station. Amelie Jarlman helped us identify periphytic algae and Ken Brown and Dave Lodge commented on an earlier version of this paper.

\section{Literature Cited}

Aho, J. 1984. Relative importance of hydrochemical and equilibrial variables on the diversity of freshwater gastropods in Finland. Pages 198-206 in A. Solem and A. C. Van Bruggen, editors. Biogeographical studies on non-marine Mollusca. E. J. Brill, Leiden, The Netherlands.

Allan, J. D. 1982. The effects of reduction in trout density on the invertebrate community of a mountain stream. Ecology 63:1444-1455.

Ball, R. C., and D. W. Hayne. 1952. Effects of the removal of the fish population on the fish-food organisms of a lake. Ecology 33:41-48.

Brönmark, C. 1988. Effects of vertebrate predation on freshwater gastropods: an exclosure experiment. Hydrobiologia 169:363-370.

1989. Interactions between epiphytes, macrophytes, and freshwater snails: a review. Journal of Molluscan Studies 55:299-311.

Brown, K. M., and D. R. DeVries. 1985. Predation and the distribution and abundance of a pulmonate pond snail. Oecologia (Berlin) 66:93-99.

Calow, P. 1973. Field observations and laboratory experiments on the general food requirements of two species of freshwater snails, Planorbis contortus Linn. and Ancylus fluviatilis Mull. Proceedings of the Malacological Society of London 40:483-489.

Carpenter, S. R. 1988. Complex interactions in lake communities. Springer-Verlag, New York, New York. USA.

Carpenter, S. R., J. F. Kitchell, and J. R. Hodgson. 1985. Cascading trophic interactions and lake productivity. BioScience 35:634-639

Carpenter, S. R., J. F. Kitchell, J. R. Hodgson, P. A. Cochran, J. J. Elser, M. M. Elser, D. M. Lodge, D. Kretchmer, X. He, and C. N. von Ende. 1987. Regulation of lake primary productivity by food web structure. Ecology 68:1863-1876. 
Cattaneo. A. 1983. Grazing on epiphytes. Limnology and Oceanography 28:124-132.

Cattaneo. A.. and J. Kalff. 1986. The effect of grazer size manipulation on periphyton communities. Oecologia (Berlin) 69:612-617.

Crowder. L. B., and W. E. Cooper. 1982. Habitat structural complexity and the interaction between bluegills and their prey. Ecology 63:1802-1813.

Diamond. J.. and T. J. Case. 1986. Community ecology. Harper and Row. New York, New York, USA.

Duggins, D. O. 1980. Kelp beds and sea otters: an experimental approach. Ecology 61:447-453.

Estes. J. A., and J. F. Palmisano. 1974. Sea otters: their role in structuring nearshore communities. Science 185:10581060.

Fretwell, S. D. 1987. Food chain dynamics: the central theory of ecology? Oikos 50:291-301.

Gilinsky, E. 1984. The role of fish predation and spatial heterogeneity in determining benthic community structure. Ecology 65:455-468.

Gilliam, J. F.. D. F. Fraser, and A. M. Sabat. 1989. Strong effects of foraging minnows on a stream benthic invertebrate community. Ecology 70:445-452.

Hairston. N.. F. E. Smith, and L. Slobodkin. 1960. Community structure, population control, and competition. American Naturalist 94:421-425.

Hanson, J. M., and W. C. Leggett. 1986. Effect of competition between two freshwater fishes on prey consumption and abundance. Canadian Journal of Fisheries and Aquatic Sciences 43:1363-1372.

Henrikson, L., H. Nyman, H. Oscarson, and J. Stenson. 1980. Trophic changes, without changes in the external nutrient loading. Hydrobiologia 68:257-263.

Hubendick. B. 1947. Die Verbraitungsverhaltnisse der limnischen Gastropoden in Südschweden. Zoologiska Bidrag från Uppsala 24:415-559.

Hurlbert. S. H. 1984. Pseudoreplication and the design of ecological field experiments. Ecological Monographs 54: 187-211.

Jones, R. C., and M. S. Adams. 1982. Seasonal variation in photosynthetic response of algae epiphytic on Myriophyllum spicatum. Aquatic Botany 13:317-330.

Kerfoot. W. C. 1987. Cascading effects and indirect pathways. Pages 57-70 in C. W. Kerfoot and A. Sih, editors. Predation: direct and indirect impacts on aquatic communities. University Press of New England, Hanover, New Hampshire, USA

Kerfoot, W. C., and A. Sih, editors. 1987. Predation: direct and indirect impacts on aquatic communities. University Press of New England, Hanover, New Hampshire, USA.

Klosiewski. S. P. 1991. Selective predation by pumpkinseed sunfish and its influence on snail assemblage structure. Dissertation. Ohio State University, Columbus, Ohio, USA.

Lauder, G. V. 1983. Functional and morphological bases of trophic specialization in sunfishes (Teleostei, Centrarchidae). Journal of Morphology 178:1-21.

Leibold, M. A. 1989. Resource edibility and the effects of predators and productivity on the outcome of trophic interactions. American Naturalist 134:922-949.

Lodge. D. M., K. M. Brown, S. P. Klosiewski, R. A. Stein, A. P. Covich, B. K. Leathers, and C. Brönmark. 1987. Distribution of freshwater snails: spatial scale and the relative importance of physicochemical and biotic factors. American Malacological Bulletin 5:73-84.

Lowe, R. L., and R. D. Hunter. 1988. Effect of grazing by Physa integra on periphyton community structure. Journal of the North American Benthological Society 7:29-36.

Lubchenco. J. 1986. Relative importance of competition and predation: early colonization of seaweeds in New England. Pages 537-555 in J. Diamond and T. J. Case, editors.
Community ecology. Harper and Row, New York, New York, USA.

Martin, T. H., L. B. Crowder, C. F. Dumas, and J. M. Burkholder. 1992. Indirect effects of fish on macrophytes in Bays Mountian Lake: evidence for a littoral trophic cascade. Oecologia (Berlin), in press.

Mazumder, A., W. D. Taylor, D. J. McQueen, and D. R. S. Lean. 1989. Effects of nutrients and grazers on periphyton phosphorus in lake enclosures. Freshwater Biology 22:405415.

McQueen, D. J., J. R. Post, and E. L. Mills. 1986. Trophic relationships in freshwater pelagic ecosystems. Canadian Journal of Fisheries and Aquatic Sciences 43:1571-1581.

Menge, B. A., and J. P. Sutherland. 1976. Species diversity gradients: synthesis of the roles of predation, competition, and temporal heterogeneity. American Naturalist 110:352369 .

Menge, B. A., and J. P. Sutherland. 1987. Community regulation: variation in disturbance, competition, and predation in relation to environmental stress and recruitment. American Naturalist 130:730-757.

Miller, T. E., and W. C. Kerfoot. 1987. Redefining indirect effects. Pages 33-38 in C. W. Kerfoot and A. Sih, editors. Predation: direct and indirect impacts on aquatic communities. University Press of New England, Hanover, New Hampshire, USA.

Mittelbach, G. G. 1984. Predation and resource partitioning in two sunfishes (Centrarchidae). Ecology 65:499-513.

- 1988. Competition among refuging sunfishes and effects of fish density on littoral zone invertebrates. Ecology 69:614-623

Mittelbach, G. G., and P. L. Chesson. 1987. Predation risk: indirect effects on fish populations. Pages 315-333 in C. W. Kerfoot and A. Sih, editors. Predation: direct and indirect impacts on aquatic communities. University Press of New England, Hanover, New Hampshire, USA.

Moreno, C. A., J. P. Sutherland, and H. F. Hara. 1984. Man as a predator in the intertidal zone of southern Chile. Oikos 42:155-160.

Morin, P. J. 1984. The impact of fish exclusion on the abundance and species composition of larval odonates: the results of short-term experiments in a North Carolina farm pond. Ecology 65:53-60

Müller, C. 1983. Uptake and accumulation of some nutrient elements in relation to biomass of an epiphytic community. Pages 147-151 in R. G. Wetzel, editor. Periphyton in freshwater ecosystems. Junk, The Hague, The Netherlands.

Northcote, T. G. 1988. Fish in the structure and function of freshwater ecosystems: a "top-down" view. Canadian Journal of Fisheries and Aquatic Sciences 45:361-379.

Oksanen, L., S. D. Fretwell, J. Arruda, and P. Niemelä. 1981. Exploitation ecosystems in gradients of primary productivity. American Naturalist 118:240-261.

Osenberg, C. W. 1989. Resource limitation, competition, and the influence of life history in a freshwater snail community. Oecologia (Berlin) 79:512-519.

Osenberg, C. W., and G. G. Mittelbach. 1990. The effects of body size on the predator-prey interaction between pumpkinseed sunfish and gastropods. Ecological Monographs 59:405-432.

Osenberg, C. W., G. G. Mittelbach, and P. C. Wainwright. 1992. Two-stage life histories in fish: the interaction between juvenile competition and adult performance. Ecology 73:255-267.

Paine, R. T. 1966. Food web complexity and species diversity. American Naturalist 100:65-75.

- 1980. Food webs: linkage, interaction strength and community structure. Journal of Animal Ecology 49:667686.

Persson, L., G. Andersson, S. F. Hamrin, and L. Johansson. 
1988. Predator regulation and primary production along the productivity gradient of temperate lake ecosystems. Pages 45-65 in S. R. Carpenter, editor. Complex interactions in lake communities. Springer-Verlag, New York, New York, USA.

Porter, K. G. 1977. The plant-animal interface in freshwater ecosystems. American Scientist 65:159-170.

Power, M. E. 1987. Predator avoidance by grazing fishes in temperate and tropical streams: importance of stream depth and prey size. Pages 333-351 in C. W. Kerfoot and A. Sih. editors. Predation: direct and indirect impacts on aquatic communities. University Press of New England. Hanover, New Hampshire, USA.

1990. Effects of fish in river food webs. Science $\mathbf{2 5 0}$ $811-814$

Reice, S. R., and R. L. Edwards. 1986. The effect of vertebrate predation on lotic macroinvertebrate communities in Quebec, Canada. Canadian Journal of Zoology 64:19301936.

Sadzikowski, M. R., and D. C. Wallace. 1976. A comparison of food habits of size classes of three sunfishes (Lepomis macrochirus Rafinesque, $L$. gibbosus Linneaus, and $L$. $c y$ anellus Rafinesque). American Midland Naturalist 95:220225.

SAS. 1988. SAS/STAT user's guide. Release 6.03 edition. SAS Institute, Cary, North Carolina, USA.

Shapiro, J.. and D. I. Wright. 1984. Lake restoration by biomanipulation. Freshwater Biology 14:371-383.

Sih. A.. P. Crowley, M. McPeek. J. Petranka, and K. Strohmeier. 1985. Predation, competition, and prey communities: a review of field experiments. Annual Review of Ecology and Systematics. 16:269-311.

Simenstad. C. A.. J. A. Estes, and K. W. Kenyon. 1978.
Aleuts, sea otters, and alternate stable-state communities. Science 200:403-411.

Steinman, A. D., C. D. McIntire, and R. R. Lowry. 1987. Effects of herbivore type and density on chemical composition of algal assemblages in laboratory streams. Journal of the North American Benthological Society 6:189-197.

Strong, D. R., D. Simberloff, L. G. Abele, and A. B. Thistle. 1984. Ecological communities. Conceptual issues and the evidence. Princeton University Press, Princeton. New Jersey, USA.

Thorp, J. H. 1986. Two distinct roles for predators in freshwater assemblages. Oikos 47:75-82.

Thorp, J. H., and E. A. Bergey. 1981a. Field experiments on response of a freshwater benthic macroinvertebrate community to vertebrate predators. Ecology 62:365-375.

Thorp, J. H., and E. A. Bergey. 1981b. Field experiments on interactions between vertebrate predators and larval midges (Diptera: Chironomidae) in the littoral zone of a reservoir. Oecologia (Berlin) 50:285-290.

Threlkeld, S. T. 1987. Experimental evaluation of trophiccascade and nutrient-mediated effects of planktivorous fish on plankton community structure. Pages 161-173 in C. W. Kerfoot and A. Sih, editors. Predation: direct and indirect impacts on aquatic communities. University Press of New England, Hanover, New Hampshire, USA.

Weber, L. M., and D. M. Lodge. 1990. Periphyton food and crayfish predators: relative roles in determining crayfish distribution. Oecologia (Heidelberg) 82:33-39.

Wetzel, R. G. 1983. Attached algal-substrate interactions: fact or myth, and when and how. Pages 207-215 in R. G. Wetzel, editor. Periphyton in freshwater ecosystems. Junk. The Hague. The Netherlands. 